\title{
Regional effects on competition-productivity relationship: a set of field experiments in two distant regions
}

\author{
Marek Sammul, Lauri Oksanen and Merike Mägi
}

\begin{abstract}
Sammul, M., Oksanen, L. and Mägi, M. 2006. Regional effects on competitionproductivity relationship: a set of field experiments in two distant regions. - Oikos
\end{abstract} 112: $138-148$.

\begin{abstract}
We studied the effect of productivity on competition intensity and the relationship between competition intensity and community species richness, using a removal experiment with the perennial plant Solidago virgaurea. The experiment was conducted in 16 different communities from two geographically distant areas (western Estonia and northern Norway). The results were compared with the results of previous experiments with Anthoxanthum odoratum from the same areas. Removal of neighbors had a positive effect on the biomass of both Solidago and Anthoxanthum, and this response was stronger in communities with higher productivity. Thus, the corrected index of relative competition intensity, CRCI, increased with increasing community productivity. Species richness was negatively correlated with CRCI in Estonia but not in Norway and not in the case of the pooled material. The results suggest that competitive exclusion operates at least in these communities which species pool is large.

Our results indicate that the relationship between competition intensity and productivity is non-linear. In our data, competition prevails in communities where living plant biomass exceeds $200 \mathrm{~g} \mathrm{~m}^{-2}$, whereas in less productive communities, competition remains undetected and direct plant-plant relationships might at times be even mutualistic. Moreover, we found that the relationship between competition intensity and productivity is strongly dependent on regional differences and is intimately connected to a concordant variation in the intensity of grazing. The least productive communities both in Estonia and in Norway are characterized by intensive grazing, which reduces importance of competition. Hence, the contrasting results corroborates the predictions of the hypothesis of exploitation ecosystems, predicting that trophic dynamics account for the relationship between competition intensity and primary productivity.
\end{abstract}

M. Sammul, Inst. of Agricultural and Environmental Sciences, Estonian Agric. Univ., Riia 181, EE-51014 Tartu, Estonia. - L. Oksanen, Dept of Ecology and Environmental Science, Umeå Univ., SE-90187 Umeå, Sweden (lauoks@utu.fi). Present address: Dept of Biology, Univ. of Turku, FIN-20014 Turku, Finland. - M. Mägi, Inst. of Botany and Ecology, Univ. of Tartu, Lai 40, EE-51005 Tartu, Estonia.

For a couple of decades, plant ecologists have intensely debated whether there is a positive relationship between productivity of plant communities and intensity of competition. One of the positions has been outlined already by Darwin (1859), who suggests that the struggle for existence in the most extreme habitats is primarily fought against 'the elements'. Grime $(1973,1979)$ develops this conjecture and argues that competition between plants becomes relaxed in stressful environments. Other ecologists have all along challenged this idea or, at least, questioned its relevance for habitats with closed vegetation. For instance, Walter (1964) and Tilman (1982, 1988), propose that competition just shifts from shoot to root environment along gradients of decreasing primary 
productivity. Many experiments have yielded results supporting Grime's conjecture (Callaghan and Emanuelsson 1985, Wilson and Keddy 1986a, Kadmon and Shmida 1990, Carlsson and Callaghan 1991, Campbell and Grime 1992, Turkington et al. 1993, Bonser and Reader 1995, Gaudet and Keddy 1995, Kadmon 1995, Callaway et al. 2002), but there are also numerous studies and meta-analyses of them where no relationship between competition intensity and primary productivity has been detected (Welden et al. 1988, Wilson and Shay 1990, DiTomasso and Aarssen 1991, Wilson and Tilman 1991a, 1991b, 1993, Gurevitch et al. 1992, Peltzer et al. 1998, Cahill 1999) or where the relationship has found to be negative (Goldberg et al. 1999).

One possible reason for the contrasting results is that the impacts of constantly low and pulsating resource levels on plant-plant interactions need not be the same (Goldberg and Novoplansky 1997). Moreover, results supporting the Walter-Tilman conjecture come primarily from small scale studies on experimentally created productivity gradients, whereas Grime's view is mainly supported by experiments conducted along large-scale natural gradients. This contrast was detected already by Goldberg and Barton (1992), who argued that the results supportive to Grime derive from co-variation between primary productivity and other factors, such as frequency of physical disturbance (Wilson and Keddy 1986a, 1986b, Barton 1991) or intensity of grazing (Louda et al. 1990). Indirect connections between grazing intensity and productivity may be created by management policies, large-scale grazing being common land use in less productive areas (Walter 1964, 1968, Gimingham 1972, Pärtel et al. 1999a, 1999b). Also natural grazing pressure may co-vary with primary productivity (Oksanen et al. 1981, Oksanen and Oksanen 2000), since grazing animals are more likely to be food limited in unproductive areas, where even low grazer densities suffice to generate intense grazing pressure, as the plants grow slowly and are thus severely influenced by any damage or loss of leaf area (Fretwell 1977, Grime 1979, Frazer and Grime 1997).

Studies of the impact of primary productivity on plant-plant interactions are often constrained by the limited range of primary productivities available in a given locality. This could even contribute to the contrasts between results of different studies; especially so if the relationship between primary productivity and competition intensity is not linear but consists of plateaus and thresholds. We thus decided to tackle the issue by means of neighbor removal experiments focusing on responses of a widespread North European grass, Anthoxanthum odoratum and an equally widespread forb, Solidago virgaurea along a large-scale productivity gradient, obtained by combining data from western Estonia and northernmost Norway. Preliminary results of the Anthoxanthum study supported the conjecture that plant-plant competition is positively correlated to primary productivity (Sammul et al. 2000), but the impact of regional differences for this result was not explored.

In the present paper, we reanalyze the Anthoxanthum data and report the results of Solidago experiments, where our attempt was to diminish the role of potential confounding factors by means of interspersion along several axes of variation, which can locally correlate with primary productivity (Hurlbert 1984, Oksanen 2004). The Solidago study thus embraces larger overlap between Estonian and North Norwegian productivity ranges, enhancing the possibilities to detect regional factors. Moreover, the least productive communities include both alkalic (Estonian alvars) and acidic (North Norwegian heaths) sites, ensuring that neither speciesspecific factors nor differences in species pool size (which is in northern Europe for historical reasons positively correlated with pH, Grubb 1987, Dynesius and Jansson 2000, Pärtel 2002) or local species richness could account for observed relationships between primary productivity and intensity of plant-plant competition.

The relationship between competition intensity and species richness has so far obtained little attention in competition literature (but see Gurevitch and Unnasch 1989, Peltzer et al. 1998), which is quite unexpected considering the direct effect competitive exclusion may have on local species richness (Cajander 1909, Gause 1934, Grime 1973, 1979, Al-Mufti et al. 1977, Connell 1978, Grytnes 2000, Rajaniemi 2003). Moreover, even the relationships between species pool and role of competitive exclusion deserves attention since large species pool means that there is more room for competitive exclusion to operate on a local scale. On the other hand, species-rich communities may be characterized by subtle niche differences, promoting coexistence, as argued already by Cajander (1909). Another scope of our work is thus to study relation between species richness and competition.

\section{Study areas}

The study was conducted in two geographically distant $(1200 \mathrm{~km})$ regions: coastal Estonia and Finnmarksvidda, northernmost Norway during 1993-95 (for Antoxanthum) and 1997-1998 (for Solidago). In Estonia, the experiment was conducted in Laelatu wooded meadow and its neighboring meadow communities $\left(58^{\circ} 35^{\prime} \mathrm{N}\right.$, $23^{\circ} 34^{\prime} \mathrm{E}$, altitudes $<25 \mathrm{~m}$ a.s.1.), within the LaelatuPuhtu-Nehatu Nature Reserve and on the adjacent Sillukse alvar (Table 1). The area belongs to the hemiboreal zone (Ahti et al. 1968) representing the transition between temperate deciduous forests and the taiga. The mean temperature for July is $+17.0^{\circ} \mathrm{C}$ and for January $-5.0^{\circ} \mathrm{C}$; the mean annual precipitation 
Table 1. Characteristics of the studied communities.

\begin{tabular}{|c|c|c|c|c|c|c|}
\hline Community & Location & $\begin{array}{l}\text { Plant } \\
\text { living biomass } \\
\left(\mathrm{g} \mathrm{m}^{-2}\right)\end{array}$ & $\begin{array}{c}\text { Plant } \\
\text { litter } \\
\left(\mathrm{g} \mathrm{m}^{-2}\right)\end{array}$ & $\begin{array}{l}\text { Cumulative } \\
\text { number of } \\
\text { species }\end{array}$ & $\begin{array}{l}\text { Elevation } \\
\text { above sea } \\
\text { level }(\mathrm{m})\end{array}$ & Main dominant plant species \\
\hline Sillukse Alvar & Estonia & 113 & 429 & 32 & $<25$ & $\begin{array}{l}\text { Festuca rubra, F. ovina, } \\
\text { Helictotrichon pratense }\end{array}$ \\
\hline Laelatu alvar & Estonia & 144 & 254 & 42 & $<25$ & $\begin{array}{l}\text { Sesleria caerulea, Carex } \\
\text { tomentosa Festuca pratensis }\end{array}$ \\
\hline $\begin{array}{l}\text { Laelatu wooded } \\
\text { meadow I }\end{array}$ & Estonia & 212 & 347 & 24 & $<25$ & $\begin{array}{l}\text { Brachypodium pinnatum, Poa } \\
\text { angustifolia, Convallaria majalis }\end{array}$ \\
\hline $\begin{array}{l}\text { Laelatu wooded } \\
\text { meadow II }\end{array}$ & Estonia & 177 & 385 & 31 & $<25$ & $\begin{array}{l}\text { Brachypodium pinnatum, Carex } \\
\text { tomentosa, Convallaria majalis }\end{array}$ \\
\hline $\begin{array}{l}\text { Laelatu wooded } \\
\text { meadow III }\end{array}$ & Estonia & 159 & 367 & 26 & $<25$ & $\begin{array}{l}\text { Brachypodium pinnatum, Carex } \\
\text { tomentosa, Convallaria majalis }\end{array}$ \\
\hline Puhtu meadow I & Estonia & 263 & 463 & 18 & $<25$ & $\begin{array}{l}\text { Brachypodium pinnatum, Carex } \\
\text { tomentosa }\end{array}$ \\
\hline Puhtu meadow II & Estonia & 359 & 387 & 32 & $<25$ & $\begin{array}{l}\text { Helictotrichon pratense, } \\
\text { Brachypodium pinnatum }\end{array}$ \\
\hline Puhtu meadow III & Estonia & 244 & 354 & 25 & $<25$ & $\begin{array}{l}\text { Brachypodium pinnatum, Carex } \\
\text { tomentosa, Sesleria caerulea, } \\
\text { Helictotrichon pubescens, H. pratense }\end{array}$ \\
\hline Snow-bed I & Norway & 95 & 300 & 13 & 580 & Salix herbacea, Festuca ovina \\
\hline Snow-bed II & Norway & 49 & 219 & 9 & 540 & $\begin{array}{l}\text { Salix herbacea, Festuca ovina, } \\
\text { Vaccinium myrtillus }\end{array}$ \\
\hline Heath & Norway & 160 & 942 & 10 & 510 & $\begin{array}{l}\text { Empetrum nigrum, Vaccinium } \\
\text { myrtillus, Arctostaphylos alpina }\end{array}$ \\
\hline Clear-cut area I & Norway & 168 & 525 & 18 & 440 & Cornus suecica, Troillius europaeus \\
\hline Clear-cut area II & Norway & 141 & 678 & 10 & 420 & Cornus suecica, Vaccinium myrtillus \\
\hline Clear-cut area III & Norway & 231 & 405 & 21 & 460 & $\begin{array}{l}\text { Cornus suecica, Vaccinium myrtillus, } \\
\text { Gymnocarpium dryopteris }\end{array}$ \\
\hline Riverside & Norway & 107 & 846 & 12 & 389 & $\begin{array}{l}\text { Vaccinium myrtillus, Empetrum } \\
\text { nigrum }\end{array}$ \\
\hline Riverbank meadow & Norway & 191 & 374 & 31 & 388 & $\begin{array}{l}\text { Trollius europaeus, Carex vaginata, } \\
\text { Vaccinium myrtillus }\end{array}$ \\
\hline
\end{tabular}

is $600 \mathrm{~mm}$. The landscape is rather flat but heterogeneous, being a mosaic of numerous small forests, scrublands, meadows, fields and urban areas. The bedrock is Silurian limestone, which creates neutral or basic site conditions, with highest $\mathrm{pH}$ values on alvars, where the bedrock is exposed.

The productivity of the Estonian study area is strongly influenced by summer droughts. The severity of this periodic drought depends on soil conditions. Areas with deeper soils retain moisture from the rains and snow of the winter. These habitats are occupied by mixed forests, unless they have been converted to cropfields or to seminatural habitats like wooded meadows, which used to be managed for production of hay and coppice (Kukk and Kull 1997). Conversely, the moisture provided by precipitation and snow-melt rapidly drains away from areas with shallow soils, often lying on leached limestone flats (recall that the whole region has been submerged during the post glacial time and is now rising from the sea.) Here, the midsummer drought is severely limiting and primary productivity is thus low. Originally, these soils supported sparse forests, but after millennia of intense use, primarily for grazing, they now are occupied by barren heath-grassland complexes, referred to as alvars (Pettersson 1958, Pärtel et al. 1999a).

In northern Norway, the experiments were conducted at the Joatkanjávri research base, Finnmarksvidda $\left(69^{\circ} 46^{\prime} \mathrm{N}, 23^{\circ} 58^{\prime} \mathrm{E}\right)$; altitudes $380-600 \mathrm{~m}$ above sea level.
The lower parts of the area belong to the hemiarctic zone, where tundra prevails but woodland patches occur in topographically favorable sites. Above the $450 \mathrm{~m}$ contour, the landscape is arctic-alpine: trees are absent and the tallest woody plants are knee-high willow shrubs. The area has a continental and relatively arid climate, annual precipitation being only $345 \mathrm{~mm}$, mean July temperature $+10^{\circ} \mathrm{C}$, and mean February temperature about $-12^{\circ} \mathrm{C}$ (Oksanen and Virtanen 1995). Rocks are primarily nutrient-poor and acidic, but nutrient-rich, schist rocks are exposed along the escarpment slope that forms the limit between the Precambrian Baltic Shield and the Scandinavian mountain chain. Thus, primary productivity is influenced by several factors (altitude, exposition, edaphic moisture, bedrock). The habitats with highest primary productivity - tall herb meadows, willow thickets, birch woodlands - are encountered on south facing parts of the escarpment slope. The least productive habitats are dry, wind-exposed ridge heaths on acidic rocks and late-melting snow-beds.

The Joatkanjávri study area lies in the migration zone of reindeer. Reindeer grazing thus mostly occurs before the growing season (April-May) and after it (September-November). The area harbors a diverse guild of microtine rodents, which reached relatively high densities during 1992-93 and 1997-98 (Ekerholm et al. 2001). Several studies concerning the dynamics of native herbivores and their impacts on the vegetation 
have been conducted (Oksanen et al. 1997, Oksanen and Oksanen 2000).

In both areas, there are many communities, where the target species, Anthoxanthum odoratum and Solidago virgaurea, are reasonably abundant, and in both areas, these habitats cover large pieces of local productivity gradients. The characteristics of the habitats where Solidago experiments were conducted are summarized in Table 1. For corresponding information concerning the Anthoxanthum study and for detailed method description of that part of the work, Sammul et al. 2000 .

\section{Material and methods}

\section{Design of Solidago experiments}

Sixteen different, primarily herbaceous, communities (8 in each country) of different productivity levels were chosen. In Estonia, 16-30 individual plants (genets) of Solidago (depending on the number of plants found in the community) and in Norway 20 plants were marked in each community in early spring 1997 and followed through two growing seasons. Initially, all genets consisted of a single ramet (sensu Harper 1977), were sterile, and had two to three leaves. In the course of the experiment most genets developed several ramets. The plants were randomly divided into two groups: removal of neighbors (=manipulation) and control. The number of plants in both groups was equal.

In order to reduce competition, the aboveground parts of all neighboring plants were removed by hand from an area with a radius of $15 \mathrm{~cm}$ around the manipulated Solidago plants. Re-growth of neighboring plants was controlled by hand weeding several times during the growing season. Although the direct manipulation was restricted to shoots, recurrent weeding influenced the overall vitality of the neighbors as indicated by the sharp decrease in the amount of regrowth already after second weeding. Thus, also competition for soil resources was reduced. Removal of the shoots of the neighbors around the already existing plants was preferred to a transplant experiment and trenching was not used, since we wanted to retain the other structural aspects of the community as well as to keep the soil intact. The latter is especially important in the tundra, where disturbance by frost or by mobile surface water is often severe and any disruption of the soil surface amplifies the impact of these factors.

Altogether 80 control and 80 manipulated plants were marked in each area (total 320 plants). Marking of the plants and the first removal of neighbors were performed in May 1997 in Estonia and in June 1997 in Norway. In both countries, this is springtime. The experiment was finished in early autumn 1998 in both countries, i.e. in late August in Norway and in mid-September in Estonia.
The biomass collected from the manipulated plots at the beginning of the experiment was separated into two fractions: living biomass and litter. Woody stems were included in the litter fraction, because we wanted to obtain biomass estimates that reflect productivity and leaf area index. To obtain a more reliable index of primary productivity, the aboveground plant parts of the field layer were collected at the time of maximum living biomass (in July in Estonia and in August in Norway) in 1997 from three randomly located samples of $10 \times 30 \mathrm{~cm}$ per community and separated in the fractions as described above. Due to high variation in the collected samples of biomass, the latter sampling procedure was repeated in all Estonian communities in 1998. All samples were dried at $78^{\circ} \mathrm{C}$ for $48 \mathrm{~h}$ and weighed to an accuracy of $0.1 \mathrm{~g}$. The procedure was also repeated for control plots at the end of the experiment in 1998.

In each plot the numbers of species were counted in an area with a radius of $7 \mathrm{~cm}$ around the experimental plants at the beginning of the experiment. Counting was repeated in midsummer and in early autumn in control plots in 1997. From these vegetation analyses, the average number of species per plot was extracted using the midsummer censuses (further referred to as the average number of species), and the cumulative number of species per community was calculated using all vegetation analyses from one community.

The numbers of leaves and ramets of Solidago were counted 3-4 times a year. At the end of both growing seasons the aboveground parts of Solidago were collected from all plots. To estimate the biomass of the belowground parts, a clod of soil with a radius of $15 \mathrm{~cm}$ and with an approximate thickness of $10-15 \mathrm{~cm}$ around each experimental plant was dug up at the end of the experiment in 1998. The depth of excavation depended on local soil conditions and was always larger than the depth of the humus layer. The belowground parts of the experimental plants were cleaned from soil using running water and separated into rhizomes and roots. All plant parts were dried at $78^{\circ} \mathrm{C}$ for $48 \mathrm{~h}$ and weighed to an accuracy of $0.01 \mathrm{~g}$.

\section{Analysis of Solidago data}

As a measure of the intensity of competition, we used the CRCI index, which is derived from the classical RCI index by correcting for its built-in mathematical flaws. First, we divided the difference between the total biomass of manipulated and control plants by the total biomass of the plant, which had performed better, to create an unbiased index with symmetric behavior at positive and negative index values, as proposed by Markham and Chanway (1996). Second, we arc sin transformed the index to linearize it (Oksanen et al. 2005). The formula for CRCI thus obtained is as follows: 
$\mathrm{CRCI}=\operatorname{arc} \sin \left(\left(\mathrm{X}_{\mathrm{r}}-\mathrm{X}_{\mathrm{c}}\right) /\left(\max \mathrm{X}_{\mathrm{r}}, \mathrm{X}_{\mathrm{c}}\right)\right)$

where $X_{r}$ is the average biomass of plants whose competitors have been removed and $X_{c}$ is the average biomass of the controls. The biomass used in the calculation is the average biomass of all plants belonging to one of the treatments in a single community. CRCI values derived from pair-wise comparisons between treatment and control plants, are presented by Oksanen et al. (2005). The data were analyzed using the program Statistica 5.0 (StatSoft 1995).

The first step in our test was to ask whether the effect of the treatment could be detected for the material as a whole and whether there was evidence for a regional difference in its magnitude (nested subset ANOVA). We then proceeded by asking whether competition has a statistically significant impact on the biomass of Solidago in a given community (post-hoc Tukey HSD test). Thereafter, we tested whether the intensity of competition $(\mathrm{CRCI})$ varied as a function of primary productivity. For this, we first divided the material to three groups, using the largest gaps in the distribution of our sites along the community biomass axis as break points. The first group consisted of four communities (one Estonian, three North Norwegians) with very low aboveground plant biomass $\left(<120 \mathrm{~g} \mathrm{~m}^{-2}\right)$. The second group consisted of seven communities (three Estonian, four North Norwegians) with medium aboveground biomass $\left(121 \ldots 200 \mathrm{~g} \mathrm{~m}^{-2}\right)$. The third group consisted of the five communities (four Estonian one North Norwegian) with aboveground plant biomass higher than $200 \mathrm{~g} \mathrm{~m}^{-2}$. This analysis was conducted using the nested subset ANOVA, with the 16 communities nested in 3 productivity categories (all factors were treated as fixed). We then applied standard regression techniques, with community-specific estimates of productivity, CRCI, litter biomass and numbers of species as input variables. We tested first for the existence of a linear relationship in the whole material, then for the Estonian and North
Norwegian records separately. Thereafter we computed residuals for data points from the two sub areas to find out whether there were differences between Estonia and northernmost Norway in the relationships between CRCI and community productivity. Finally, we conducted corresponding analyses concerning the relationship between CRCI and local species richness.

\section{Reanalysis of Anthoxanthum data}

For Anthoxanthum, a simplified version of the above procedure was applied to avoid unnecessary duplication of already published work (Sammul et al. 2000). We first computed the significance of community specific responses on the basis of biomass of manipulated and control shoots. Thereafter, we proceeded to compute CRCI-values for each community, and to analyze trends in the whole material, in each region and in residuals following the same procedure, as in the case of Solidago.

\section{Results}

\section{The effect of the treatment, community biomass, and region on Solidago}

In the ANOVA based on the entire material, the main effects of country (Estonia vs Norway), treatment (manipulation vs control), and community (16 communities, nested in two countries), as well as interactions between country and treatment, and community and treatment were all statistically significant for aboveground biomass of Solidago (Table 2). The response of belowground biomass of Solidago to removal of neighbors was only marginally significant, whereas differences between communities and countries were strong (Table 2). The response of total biomass was mainly determined by the response of aboveground biomass and

Table 2. Results of the nested subset ANOVA ('community' is nested in 'country'). Statistically significant differences ( $\mathrm{p}<0.05)$ are in bold script.

\begin{tabular}{|c|c|c|c|c|c|c|c|}
\hline Dependent variable & Source of variation & $\begin{array}{c}\mathrm{df} \\
\text { Effect }\end{array}$ & $\begin{array}{c}\text { MS } \\
\text { Effect }\end{array}$ & $\begin{array}{c}\text { df } \\
\text { Error }\end{array}$ & $\begin{array}{l}\text { MS } \\
\text { Error }\end{array}$ & $\mathrm{F}$ & $\mathrm{p}$ \\
\hline Aboveground biomass & $\begin{array}{l}\text { country } \\
\text { treatment } \\
\text { community (country) } \\
\text { country } \times \text { treatment } \\
\text { community } \times \text { treatment }\end{array}$ & $\begin{array}{r}1 \\
1 \\
14 \\
1 \\
14\end{array}$ & $\begin{array}{r}69.4 \\
22.1 \\
3.6 \\
16.3 \\
1.5\end{array}$ & $\begin{array}{l}282 \\
282 \\
282 \\
282 \\
282\end{array}$ & $\begin{array}{l}0.80 \\
0.80 \\
0.80 \\
0.80 \\
0.80\end{array}$ & $\begin{array}{l}86 \\
27 \\
4.5 \\
20 \\
1.8\end{array}$ & $\begin{aligned}< & \mathbf{0 . 0 0 0 1} \\
< & \mathbf{0 . 0 0 0 1} \\
< & \mathbf{0 . 0 0 0 1} \\
< & \mathbf{0 . 0 0 0 1} \\
& \mathbf{0 . 0 3 6}\end{aligned}$ \\
\hline Belowground biomass & $\begin{array}{l}\text { country } \\
\text { treatment } \\
\text { community (country) } \\
\text { country } \times \text { treatment } \\
\text { community } \times \text { treatment }\end{array}$ & $\begin{array}{r}1 \\
1 \\
14 \\
1 \\
14\end{array}$ & $\begin{array}{r}85.8 \\
2.6 \\
5.0 \\
3.8 \\
0.8\end{array}$ & $\begin{array}{l}282 \\
282 \\
282 \\
282 \\
282\end{array}$ & $\begin{array}{l}0.82 \\
0.82 \\
0.82 \\
0.82 \\
0.82\end{array}$ & $\begin{array}{r}104 \\
3.2 \\
6.1 \\
4.6 \\
0.92\end{array}$ & $\begin{array}{c}<\mathbf{0 . 0 0 0 1} \\
0.076 \\
<\mathbf{0 . 0 0 0 1} \\
\mathbf{0 . 0 3 3} \\
0.534\end{array}$ \\
\hline Total biomass & $\begin{array}{l}\text { country } \\
\text { treatment } \\
\text { community (country) } \\
\text { country } \times \text { treatment } \\
\text { community } \times \text { treatment }\end{array}$ & $\begin{array}{r}1 \\
1 \\
14 \\
1 \\
14\end{array}$ & $\begin{array}{r}310 \\
40 \\
16 \\
36 \\
3.9\end{array}$ & $\begin{array}{l}282 \\
282 \\
282 \\
282 \\
282\end{array}$ & $\begin{array}{l}2.47 \\
2.47 \\
2.47 \\
2.47 \\
2.47\end{array}$ & $\begin{array}{c}125 \\
16 \\
6.6 \\
14 \\
1.6\end{array}$ & $\begin{array}{c}<\mathbf{0 . 0 0 0 1} \\
<\mathbf{0 . 0 0 0 1} \\
<\mathbf{0 . 0 0 0 1} \\
\mathbf{0 . 0 0 0 2} \\
0.081\end{array}$ \\
\hline
\end{tabular}


yielded fairly similar results, except for the interaction effect of community and treatment which became only marginally significant (Table 2).

The majority of the within-community tests of the effect of the treatment (Tukey HSD test) failed to reveal significant differences in the biomass between the control plants and the manipulated plants. On the community level, significant treatment responses of Solidago were only found in two cases, both in Estonia (Laelatu wooded meadow III: $\mathrm{p}<0.036$, Puhtu seashore meadow III: $p<0.013)$. In both cases, the difference in aboveground biomass accounted for the result $(\mathrm{p}<0.022$ and $\mathrm{p}<0.0001$ respectively). No significant differences in belowground biomass were found.

The effect of productivity group (three different levels of aboveground biomass) on total biomass of Solidago and the interaction of productivity group with treatment effects were also significant (Table 3), indicating that the effect of neighbor removal is dependent on productivity of the area. Post hoc test (Tukey's HSD) show that the treatment response of Solidago was significant in the most productive community category $(\mathrm{p}=0.03)$, but not in the intermediate category $(\mathrm{p}=0.57)$ or in the least productive category $(\mathrm{p}=0.99)$.

In the regression analysis based on the whole material, we found that CRCI was positively correlated with our index of primary productivity. (Table 4, Fig. 1). The $95 \%$ confidence bands showed that in the productivity range $0 \ldots 170 \mathrm{~g} \mathrm{~m}^{-2}$ the CRCI did not differ significantly from 0 , but starting from productivity over $170 \mathrm{~g} \mathrm{~m}^{-2} \mathrm{CRCI}$ became significantly positive. The estimated y-intercept of the regression line was statistically indistinguishable from zero (Table 4).The residuals of regression $(0.7 \pm$ 0.08 for the Estonian data; $0.7 \pm 0.07$ for the Norwegian data) were significantly different from each other $(\mathrm{p}<$ 0.001). The regression of CRCI on biomass axis was tentative $(p=0.096)$ for Estonian data, with virtually equal slope and an intercept indistinguishable from zero. No relationship between plant living biomass of the community and CRCI was observed for Norwegian data (Table 4). Results derived from pair-wise comparisons between treatment and control plants yielded practically identical results, so did results obtained applying the $\operatorname{lnRR}$ and RNE index (Oksanen et al. 2005).

Table 3. The effect of removal of neighbors (treatment) in areas with different productivity (productivity group) on total biomass of Solidago, as tested with two-way ANOVA. Statistically significant differences $(\mathrm{p}<0.05)$ are in bold script.

\begin{tabular}{lcccccc}
\hline $\begin{array}{l}\text { Source of } \\
\text { variation }\end{array}$ & $\begin{array}{c}\mathrm{df} \\
\text { Effect }\end{array}$ & $\begin{array}{c}\mathrm{MS} \\
\text { Effect }\end{array}$ & $\begin{array}{c}\mathrm{df} \\
\text { Error }\end{array}$ & $\begin{array}{c}\text { MS } \\
\text { Error }\end{array}$ & F & $\mathrm{p}$ \\
\hline $\begin{array}{l}\text { Treatment } \\
\text { Productivity } \\
\text { group }\end{array}$ & 1 & 25.97 & 308 & 3.98 & 6.52 & $\mathbf{0 . 0 1 1}$ \\
$\begin{array}{c}\text { Treatment } \times \\
\text { productivity } \\
\text { group }\end{array}$ & 2 & 21.04 & 308 & 3.98 & 5.28 & $<\mathbf{0 . 0 0 6}$ \\
\hline
\end{tabular}

Table 4. Relationships between community aboveground biomass (independent variable) and CRCI (dependent variable) in different subsets of data (countries). Statistically significant $\mathrm{p}$-values $(\mathrm{p}<0.05)$ are in bold script.

\begin{tabular}{lcccc}
\hline Country & Regression & $\mathrm{R}^{2}$ & $\begin{array}{c}\mathrm{p} \text {-value } \\
\text { of slope }\end{array}$ & $\begin{array}{c}\mathrm{p} \text {-value of } \\
\text { intercept }\end{array}$ \\
\hline Estonia & $\mathrm{y}=-0.15+0.0023 \mathrm{x}$ & 0.393 & 0.096 & 0.601 \\
Norway $\mathrm{y}=-0.07+0.0005 \mathrm{x}$ & 0.024 & 0.712 & 0.708 \\
$\begin{array}{l}\text { Estonia }+\mathrm{y}=-0.25+0.0023 \mathrm{x} \\
\text { Norway }\end{array}$ & 0.371 & 0.012 & 0.128 \\
\hline
\end{tabular}

\section{The effect of the treatment, community biomass, and region on Anthoxanthum}

The response of Anthoxanthum to removal of neighbors was statistically significant in all Estonian communities and in the most productive North Norwegian one (Fig. 2). The change in the indices for primary productivity and competition intensity influenced the location of the data points (Fig. 2, compare with Fig. 2B in Sammul et al. 2000) but had no impact on the statistical significance of the regression between competition intensity and community productivity, which remained significant for the pooled data $(\mathrm{p}=0.02)$ and had an $\mathrm{y}$-intercept statistically indistinguishable from zero $(\mathrm{p}=$ 0.56). The residuals of regression for Estonia tend to be positive (mean +0.235 ), whereas negative residuals are obtained for North Norwegian communities (mean $-0.156)$. The difference between the residuals for the two areas approaches statistical significance $(\mathrm{p}=$ 0.0547). When treated separately, neither the Estonian $\left(\mathrm{R}^{2}=0.012, \mathrm{p}=0.837\right)$ nor the North Norwegian $\left(\mathrm{R}^{2}=\right.$ $0.002, \mathrm{p}=0.908)$ communities showed the slightest

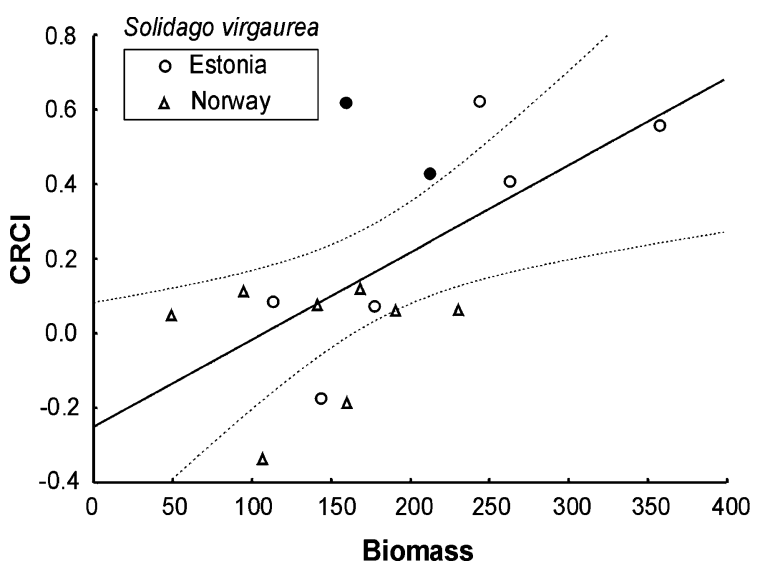

Fig. 1. Relationships between average community living biomass and competition intensity (CRCI) estimated with Solidago virgaurea. Regression is presented for the pooled Estonian and Norwegian data and it is statistically significant at $\mathrm{p}<0.013$; for the results of regression see Table 4 . Solid symbols indicate communities where the effect of removal of neighbors is statistically significant $(\mathrm{p}<0.05$, Tukey HSD test), open symbols denote communities where such treatment effect is nonsignificant. 


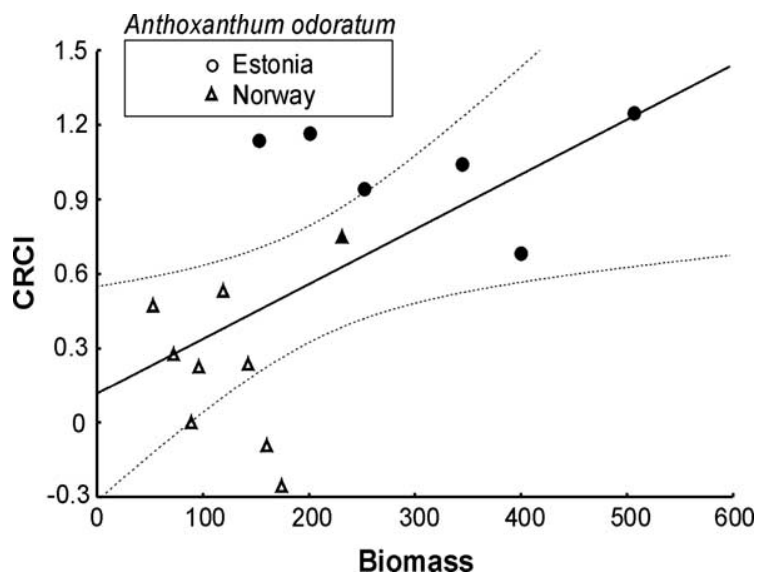

Fig. 2. Relationships between average community living biomass and competition intensity (CRCI) estimated with Anthoxanthum odoratum. Regression is presented for the pooled Estonian and Norwegian data and it is statistically significant at $\mathrm{p}<0.02$. Solid symbols indicate communities where the effect of removal of neighbors is statistically significant $(p<0.05$, Tukey HSD test), open symbols denote communities where such treatment effect is non-significant. For detailed results Sammul et al. 2000.

indications for linear relationship between primary productivity and competition intensity.

\section{Relationships between CRCI and community species richness}

We did not find any correlation between CRCI and community species richness for the pooled data. However, there was a negative correlation between both average and cumulative species richness and CRCI in Estonia (Fig. 3, Table 5). No significant relationship was found between either measure of species richness and CRCI in Norway.

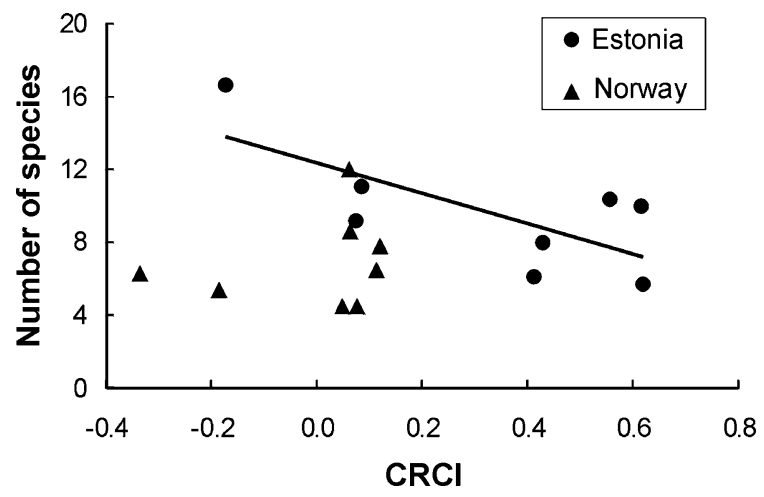

Fig. 3. Relationships between average community species richness (number of species per $155 \mathrm{~cm}^{2}$ in the midsummer) and competition intensity (CRCI) in Solidago studies. Regression (significant at $\mathrm{p}<0.05$ ) is presented only for the Estonian data; for the results of regression see Table 5 .

\section{Discussion}

\section{Competition, facilitation, and primary productivity}

The relationship between competition intensity and community productivity, emerging from analyses of over-all patterns (Fig. 1, 2) corresponds to the contrast between competition intensity in boreal-subalpine and arctic-alpine systems reported by Callaway et al. (2002), indicating that competition intensity increases with increasing community productivity (Grime 1973, Berendse 1983, Wilson and Keddy 1986a, 1986b, Campbell and Grime 1992, Kadmon 1995). Moreover, as the y-intercept of the regression lines for Anthoxanthum and Solidago is statistically indistinguishable from zero, our results could be interpreted as supportive for the idea that plant-plant interactions cease to be competitive and might even become mutualistic in most extreme environments as proposed by Callaghan and Emanuelsson (1985).

It seems unlikely that a shift from the prevalence of aboveground competition to belowground competition alone (Tilman 1988, Belcher et al. 1995) would suffice to account for these results. Even though our manipulation of belowground competition was indirect, recurrent removal of shoots reduces the overall vitality of the neighboring plants. It is reasonable to assume that the correlation between the growth rate of roots and primary productivity is positive, because the factors reducing primary productivity tend to have a negative impact on all growth processes. Low annual rates of root growth are especially probable in snow-bed communities, which differ from more productive communities primarily in having a shorter and cooler growing season. We can thus expect that the impact of our treatment on belowground competition in less productive communities was (at least in relative terms) either stronger than or equal to the impact in more productive communities.

Detailed analyses of our results nevertheless refute the conjecture of uniform and linear decrease in the intensity of plant-plant competition along gradients of decreasing primary productivity. Intense competition prevails in communities where the peak biomass of forbs, leaves and annual increments of woody shoots exceeds $200 \mathrm{~g} \mathrm{~m}^{-2}$, whereas in less productive communities, the intensity of plant-plant competition appears to be close to zero, and direct plant-plant relationships might be even mutualistic (Carlsson and Callaghan 1991, Olofsson 2005). Moreover, both the ANOVA for Solidago and the analysis of residuals for both species indicated that regional factors, not directly related to primary productivity, influence the intensity of plant-plant competition. In our North Norwegian material, solid evidence for competition between plants was found just in the most productive community included in the $A n$ thoxanthum study. Similarly, Carex bigelowii has shown to be influenced by competition only in relatively 
Table 5. Relationships between the corrected coefficient of relative competition intensity (CRCI) (independent variable $\mathrm{x}$ ) and community species richness (dependent variable y: average number of species per $155 \mathrm{~cm}^{2}$ or cumulative number of species per community). Statistically significant $p$-values $(p<0.05)$ are in bold script.

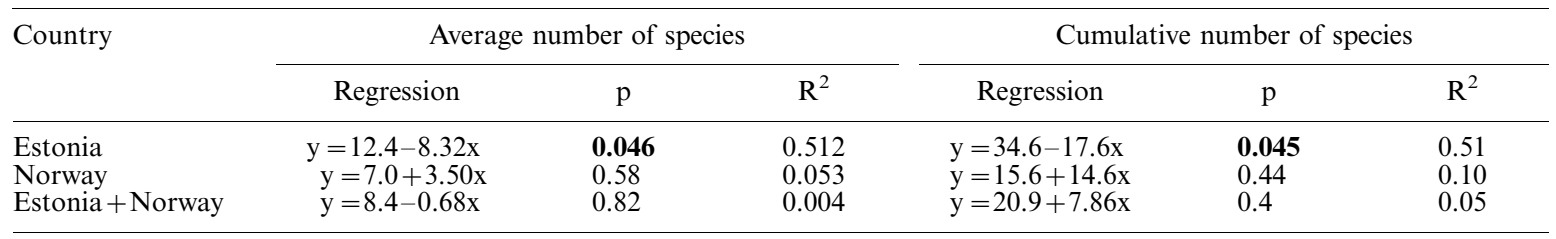

productive North Norwegian habitats (Olofsson et al. 2002, Olofsson 2005). Without this evidence there would be little support for the existence of detectable plantplant competition even in the most productive North Norwegian habitats.

As pointed out by Goldberg and Barton (1992), indications of low intensity of plant-plant competition in unproductive habitats need not indicate that low productivity or stress per se would reduce the intensity of competition between plants. Indeed, the non-linearity of the response and the importance of the 'country factor', detected in our study, argue against the existence of any simple and straightforward causal relation between primary productivity and the intensity of plant-plant competition. In Estonia, low intensities of plant-plant competition were primarily found on alvars, which are products of long-lasting intense grazing (Pärtel et al. 1999a) and do not even persist without grazing or mowing (Pettersson 1958, Rosén 1982, Pärtel et al. 1999b). On the mountains and tundra areas of northern Norway and Finland, predators are practically restricted to the most productive habitats, where they also seem to control grazing mammals, thus allowing plant biomass to build up and plant-plant competition to become intense (Oksanen et al. 1992, 1997, 1999, Ekerholm et al. 2004, Hambäck et al. 2004, Aunapuu 2004). In less productive arctic-alpine habitats, grazers appear to be food-limited (Moen et al. 1993, Oksanen et al. 1997, Turchin et al. 2000, Ekerholm et al. 2004) and plant biomass appears to be limited by grazing mammals (Aunapuu 2004). Intensity of plant-plant competition is weak in such areas, but long-lasting exclusion of grazers leads to intensification of plant-plant competition (Virtanen et al. 1997, Olofsson et al. 2002), and to increased abundance of fairly tall forbs like Solidago virgaurea (Virtanen 1998). Moreover, intense pre-emptive competition prevails in extreme high-alpine habitats, where vegetation only exists as small patches and grazing mammals are thus absent (Olofsson et al. 1999). The evidence summarized above thus suggests that the impact of primary productivity on the intensity of plant-plant competition is primarily indirect, mediated via productivity-driven changes in grazer-plant dynamics and is also influenced by past and present land use in areas with reasonably dense human population.

\section{Competition and local species diversity}

It is often proposed that undisturbed competition for a single limiting resource, such as light or space, results in low species diversity and that high productivity increases the likelihood of a strong limitation by a single resource (Grime 1973, Connell 1978, Tilman 1988, Huston and DeAngelis 1994). In studies reporting decreasing species richness with increasing productivity, increasing competition for a single resource is often proposed as an explanation for the pattern (Grace and Pugesek 1997, Grytnes 2000, reviewed by Rajaniemi 2003). However, experiments concerning the relationship between competition and species diversity have been seldom conducted and the two issues are rarely explicitly dealt with within the same study (but Grime 1973, Gurevitch and Unnasch 1989, Goldberg and Miller 1990, Goldberg and Estabrook 1998, Lepš 1999).

Our study contributes to this still small body of evidence by suggesting that the relationship between competition intensity and species diversity is strong in systems with a large species pool, such as the Estonian grasslands and meadows on limestone bedrock (Pärtel et al. 2000). The same pattern is found even in limeinfluenced habitats of northernmost Fennoscandia. In Kalliola's (1939) material, representing Finnish tundra areas adjacent to our North Norwegian sites, the maximally productive willow thickets harbor only 10-20 (mean 13.9) vascular species and 3-6 (mean 4.6) cryptogam species per $4 \mathrm{~m}^{2}$. The less productive Dryas heaths on lime-rich soils harbor 23-30 vascular species (mean 26.1) and 11-26 cryptogam species (mean 16.3) per $4 \mathrm{~m}^{2}$. Within the Scandinavian mountain chain proper, where lime-rich habitats are more common, their species richness is even higher (Virtanen and Eurola 1997). Thus, the crucial factor determining the size of species pool and number of coexisting species seems to be the bedrock, not the latitudinal position of the system (Pärtel 2002).

In the North Norwegian habitats included in our study, species richness is consistently on the same low level as found in the most productive Estonian communities with highest intensity of competition. It would be tempting to interpret this as evidence for the conjecture that in species poor areas, interspecific niche differences between potentially coexisting plants are sufficient to 
allow for their competitive coexistence. Recall, however, that the soft shales and the impact of running water, which account for the relatively high productivity of the most luxuriant study sites in northernmost Norway, probably influence $\mathrm{pH}$ and thus the pool of the species capable of growing in the site. Hence, it is possible that the negative relationship of local species diversity to productivity and competition intensity exists generally even in northern Fennoscandia, but the trend is masked in our material, because the decreasing intensity of competition happens to be associated with decreasing $\mathrm{pH}$ and hence with the decreasing size of the species pool (Grubb 1987, Pärtel 2002). In the case of studied Estonian communities, however, the species pools of more productive and less productive communities do not differ, since they are all calcareous grasslands within relatively small geographical range and share large number of the species. Therefore, the number of species capable for immigration and successful growth is quite high and decreasing intensity of competitive interactions allows for more species to establish and persist, thus, leading to high number of coexisting species.

While species pool indeed sets the upper limit for the number of coexisting species (Zobel 1997, Gaston 2000, Herben 2000), local processes determine the number of species actually coexisting in a given community. This study shows that competition leads to decrease in number of coexisting species when the productivity of the community is sufficiently high and the buildup of plant biomass is undisturbed. Our results are in good concordance with the very rapid decrease in species richness in abandoned wooded meadows (Kukk and Kull 1997) and on those alvars, which are no longer grazed (Pettersson 1958, Rosén 1982). Moreover, local processes, such as cessation of grazing, may even influence species pool, as exemplified by the currently threatened status of several alvar plants and decreasing abundance of red-listed arctic-alpine plants on mountains from where reindeer had been excluded (Olofsson and Oksanen 2005). For us, it is easier to understand the origin of both large-scale patterns (e.g. high species diversity on neutral and nutrient-rich soils in Eurasia and the reverse situation in Australia and South Africa) as well as local patterns, if we assume that local processes are crucial for their development and that the role of long time spans and climatic stability (Zobel 1992, Tilman 1997, Grace 1999, Smith and Knapp 2001) is that under these conditions, evolution driven by local processes can successively enrich the flora. If, however, undisturbed competition for a single resource prevails, competitive exclusion will rule, and no amount of time and stability will lead to increased species richness, neither locally nor regionally.

Acknowledgements - We thank P. Vissak for permission to carry out the experiment in the Laelatu-Puhtu Nature Reserve as well as the Norwegian local authorities and the Kautokeino reindeer herdsmen's association for permission to perform the experiment at Joatka. Kalevi Kull and Meelis Pärtel made several valuable comments on this manuscript. This work was supported by the Royal Academy of Sweden, the Swedish Council for Natural Sciences, Swedish Council for Agriculture and Forestry Research, Estonian Science Foundation, grant no 6048, and the Estonian Polar Fund.

\section{References}

Ahti, T., Hämet-Ahti, L. and Jalas, J. 1968. Vegetation zones and their sections in northwestern Europe. - Ann. Bot. Fenn. 5: 169-211.

Al-Mufti, M. M., Sydes, C. L., Furness, S. B. et al. 1977. A quantiative analysis of shoot phenology and dominance in herbaceous vegetation. - J. Ecol. 65: 759-791.

Aunapuu, M. 2004. Predators in low arctic tundra and their impact on community structure and dynamics. - PhD thesis, Univ. of Umeå.

Barton, A. 1991. Factors controlling the elevational positions of pines in the Ciracahua Mountains: competition, drought and fire. - PhD thesis, Univ. of Michigan, Ann Arbor, Michigan.

Belcher, J. W., Keddy, P. A. and Twolan-Strutt, L. 1995. Root and shoot competition intensity along a soil depth gradient. - J. Ecol. 83: 673-682.

Berendse, F. 1983. Interspecific competition and niche differentiation between Plantago lanceolata and Anthoxanthum odoratum in a natural hayfield. - J. Ecol. 71: 379-390.

Bonser, S. P. and Reader, R. J. 1995. Plant competition and herbivory in relation to vegetation biomass. - Ecology 76 : $2176-2183$.

Cahill, J. F. 1999. Fertilization effects on interactions between above- and belowground competition in an old field. - Ecology 80: 466-480.

Cajander, A. K. 1909. ber die Waldtypen. - Acta For. Fenn. 1: $1-175$.

Callaghan, T. V. and Emanuelsson, U. 1985. Population structure and processes of tundra plants and vegetation. - In: White, J. (ed.), The population structure of vegetation. Dr. W. Junk Publishers, pp. 349-399.

Callaway, R. M., Brooker, R. W., Choler, P. et al. 2002. Positive interactions among alpine plants increase with stress. - Nature 417: 844-848.

Campbell, B. D. and Grime, J. P. 1992. An experimental test of plant strategy theory. - Ecology 73: 15-29.

Carlsson, B. A. and Callaghan, T. V. 1991. Positive plant interactions in tundra vegetation and the importance of shelter. - J. Ecol. 79: 973-983.

Connell, J. H. 1978. Diversity in tropical rain forest and coral reefs. - Science 199: 1302-1310.

DiTomasso, A. and Aarssen, L. W. 1991. Effect of nutrient level on competition intensity in the field for three coexisting grass species. - J. Veg. Sci. 2: 513-522.

Darwin, C. 1859 . The origin of species by means of natural selection. - John Murray, London.

Dynesius, M. and Jansson, R. 2000. Evolutionary consequences of changes in species' geographical distributions driven by Milankovich climate oscillations. - Proc. Natl Acad. Sci. USA 97: 9115-9120.

Ekerholm, P, Oksanen, L. and Oksanen, T. 2001. Long-term dynamics of voles and lemmings at the timberline and above the willow limit as a test of theories on trophic interactions. - Ecography 24: 555-568.

Ekerholm, P., Oksanen, L., Oksanen, T. et al. 2004. The impact of short term predator removal on vole dynamics in a subarctic-alpine habitat complex. - Oikos 106: 457-468.

Frazer, L. H. and Grime, J. P. 1997. Primary productivity and trophic dynamics investigated in a North Derbyshire, U.K., dale. - Oikos 81: 499-508. 
Fretwell, S. D. 1977. The regulation of plant communities by food chains exploiting them. - Persp. Biol. Med. 20: 169185.

Gaston, K. J. 2000. Global patterns in biodiversity. - Nature 405: $220-227$.

Gaudet, C. L. and Keddy, P. A. 1995. Competitive performance and species distribution in shoreline plant communities: a comparative approach. - Ecology 76: 280-291.

Gause, G. F. 1934. The struggle for existence. - Williams and Wilkins, Baltimore.

Gimingham, C. H. 1972. Ecology of heathlands. - Chapman \& Hall.

Goldberg, D. E. and Miller, T. E. 1990. Effects of different resource additions on species diversity in an annual plant community. - Ecology 71: 213-225.

Goldberg, D. E. and Barton, A. M. 1992. Patterns and consequences of interspecific competition in natural communities: a review of field experiments with plants. - Am. Nat. 139: 771-801.

Goldberg, D. E. and Novoplansky, A. 1997. On the relative importance of competition in unproductive environments. - J. Ecol. 85: 409-418.

Goldberg, D. E. and Estabrook, G. F. 1998. Separating the effects of number of individuals sampled and competition on species diversity: an experimental and analytic approach. - J. Ecol. 86: 983-988.

Goldberg, D. E., Rajaniemi, T., Gurevitch, J. et al. 1999. Empirical approaches to quantifying interaction intensity: competition and facilitation along productivity gradients. - Ecology 80: 1118-1131.

Grace, J. B. 1999. The factors controlling species density in herbaceous plant communities: an assessment. - Persp. Plant Ecol. Evol. Syst. 2: 1-28.

Grace, J. B. and Pugesek, B. H. 1997. A structural equation model of plant species richness and its application to coastal wetland. - Am. Nat. 149: 436-460.

Grime, J. P. 1973. Competitive exclusion in herbaceous vegetation. - Nature 242: 344-347.

Grime, J. P. 1979. Plant strategies and vegetation processes. - John Wiley and Sons.

Grubb, P. J. 1987. Global trends in species richness in terrestrial vegetation: a review from the Northern Hemisphere. - In: Gee, J. H. R. and Giller, P. S. (eds), Organization of communities: past and present. Blackwell, pp. 99-118.

Grytnes, J. A. 2000. Fine-scale vascular plant species richness in different alpine vegetation types: relationships with biomass and cover. - J. Veg. Sci. 11: 87-92.

Gurevitch, J. and Unnasch, R. S. 1989. Experimental removal of a dominant species at two levels of soil fertility. - Can. J. Bot. 67: $3470-3477$.

Gurevitch, J., Morrow, L. L., Wallace, A. et al. 1992. A metaanalysis of competition in field experiments. - Am. Nat. 140: 539-572.

Hambäck, P. A., Oksanen, L., Ekerholm, P. et al. 2004. Predators indirectly protect tundra plants by reducing herbivore abundance. - Oikos 106: 85-92.

Harper, J. 1977. Population biology of plants. - Academic Press.

Herben, T. 2000. Correlation between richness per unit area and the species pool cannot be used to demonstrate the species pool effect. - J. Veg. Sci. 11: 123-126.

Huston, M. A. and DeAngelis, D. L. 1994. Competition and coexistence: the effects of resource transport and supply rates. - Am. Nat. 144: 954-977.

Hurlbert, S. H. 1984. Pseudoreplication and the design of ecological field experiments. - Ecol. Monogr. 54: 187-211.

Kadmon, R. 1995. Plant competition along soil moisture gradients: a field experiment with the desert annual Stipa capensis. - J. Ecol. 83: 253-262.

Kadmon, R. and Shmida, A. 1990. Competition in a variable environment: an experimental study in a desert annual plant population. - Isr. J. Bot. 39: 403-412.
Kalliola, R. 1939. Pflanzensoziologische Untersuchungen in der alpinen Stufe Finnisch-Lapplands. - Ann. Bot. Soc. Vanamo 13: 1-321.

Kukk, T. and Kull, K. 1997. Puisniidud [Wooded meadows, in Estonian]. - Estonia Maritima 2: 1-249.

Lepš, J. 1999. Nutrient status, disturbance and competition: an experimental test of relationships in a wet meadow. - J. Veg. Sci. 10: 219-230.

Louda, S. M., Keeler, K. H. and Holt, R. D. 1990. Herbivore influences on plant performance and competitive interactions. - In: Grace, J. B. and Tilman, D. (eds), Persp. Plant Competition. Academic Press, pp. 413-444.

Markham, J. H. and Chanway, C. P. 1996. Measuring plant neighbour effects. - Funct. Ecol. 10: 548-549.

Moen, J., Lundberg, P. A., Ekerholm, P. et al. 1993. Lemming grazing on snowbed vegetation during a population peak, northern Norway. - Arct. Alp. Res. 25: 130-135.

Oksanen, L. 2004. The devil lies in details: reply to Stuart Hurlbert. - Oikos 104: 598-605.

Oksanen, L. and Virtanen, R. 1995. Topographic, altitudinal and regional patterns in continental and suboceanic heath vegetation of northern Fennoscandia. - Acta Bot. Fenn. 153: $1-80$.

Oksanen, L. and Oksanen, T. 2000. The logic and realism of the hypothesis of exploitation ecosystems. - Am. Nat. 155: $703-723$

Oksanen, L., Fretwell, S. D., Arruda, J. et al. 1981. Exploitation ecosystems in gradients of primary productivity. - Am. Nat. 118: $240-261$.

Oksanen, L., Aunapuu, M., Oksanen, T. et al. 1997. Outlines of food webs in a low arctic tundra landscape in relation to three theories of trophic dynamics. - In: Gange, A. C. and Brown, V. K. (eds), Multitrophic interactions in terrestrial systems. Blackwell, pp. 351-373.

Oksanen, L., Sammul, M. and Grünthal, M. 2005. On the indices of plant-plant competition and their pitfalls. - Oikos 112: 149-155.

Oksanen, T., Oksanen, L. and Norberg, M. 1992. Habitat use of small mustelids in a tundra landscape: a test of the hypothesis of patchy exploitation systems. - Ecography 15: $237-244$.

Oksanen, T., Schneider, M., Rammul, Ü. et al. 1999. Dynamics of voles on the North Fennoscandian tundra in relation to the hypothesis of exploitation ecosystems. - Oikos 86: 463478.

Olofsson, J. 2005. Positive and negative plant-plant interactions in two contrasting arctic-alpine plant communities. - Arct. Alp. Antarct. Res., in press.

Olofsson, J., and Oksanen, L. 2005. Effects of reindeer density on plant diversity in the Fennoscandian mountain chain. - In: Haugerud, R. E. (ed.), Proc. 11th Arctic Ungulate Conf., Saariselkä, Finland Rangifer, 25: 5-18.

Olofsson, J., Moen, J. and Oksanen, L. 1999. On the balance between positive and negative plant interactions in harsh environments. - Oikos 86: 539-543.

Olofsson, J., Moen, J. and Oksanen, L. 2002. Effects of herbivory on competition intensity and species diversity in two arctic-alpine tundra communities with different productivity. - Oikos 96: 507-515.

Pärtel, M. 2002. Local plant diversity patterns and evolutionary history at the regional scale. - Ecology 83: 2361-2366.

Pärtel, M., Kalamees, R., Zobel, M. et al. 1999a. Alvar grasslands in Estonia: variation in species composition and community structure. - J. Veg. Sci. 10: 561-568.

Pärtel, M., Mändla, R. and Zobel, M. 1999b. Landscape history of a calcareous (alvar) grassland in Hanila, western Estonia, during the last three hundred years. - Landscape Ecol. 14: 187-196.

Pärtel, M., Zobel, M., Liira, J. et al. 2000. Species richness limitations in productive and oligotrophic plant communities. - Oikos 90: 191-193. 
Peltzer, D. A., Wilson, S. D. and Gerry, A. K. 1998. Competition intensity along a productivity gradient in a low-diversity grassland. - Am. Nat. 151: 465-476.

Pettersson, B. 1958. Dynamik och konstans i Gotlands flora och vegetation. [Dynamics and constancy in the flora and vegetation of Gotland, in Swedish with German summary]. - Acta Phytogeogr. Suec. 40: 1-288.

Rajaniemi, T. K. 2003. Explaining productivity-diversity relationships in plants. - Oikos 101: 449-457.

Rosén, E. 1982. Vegetation development and sheep grazing in limestone grasslands of south Öland Sweden. - Acta Phytogeogr. Suec. 72: 1-104.

Sammul, M., Kull, K., Oksanen, L. et al. 2000. Competition intensity and its importance: results of field experiments with Anthoxanthum odoratum. - Oecologia 125: $18-25$.

Smith, M. D. and Knapp, A. K. 2001. Size of the local species pool determines invasibility of a C4-dominated grassland. - Oikos 92: 55-61.

StatSoft. Inc. 1995. Statistica for Windows (computer program manual). - StatSoft Inc., Tulsa.

Tilman, D. 1982. Resource competition and community structure. - Princeton Univ. Press.

Tilman, D. 1988. Plant strategies and the dynamics and structure of plant communities. - Princeton Univ. Press.

Tilman, D. 1997. Community invasibility, recruitment limitation, and grassland biodiversity. - Ecology 78: 81-92.

Turchin, P., Oksanen, L., Ekerholm, P. et al. 2000. Lemmings: prey or predators. - Nature 405: 562-564.

Turkington, R., Klein, E. and Chanway, C. P. 1993. Interactive effects of nutrients and disturbance: an experimental test of plant strategy theory. - Ecology 74: 863-878.

Virtanen, R. J. 1998. Impact of grazing and neighbour removal on a heath plant community transplanted onto a snowbed site, NW Finnish Lapland. - Oikos 81: 359-367.
Virtanen, R. J. and Eurola, S. 1997. Middle northern (oro)arctic vegetation of northern Europe: community types and vegetation gradients. - Acta Phytogeogr. Suec. 82: 1-60.

Virtanen, R. J., Henttonen, H. and Laine, K. 1997. Lemming grazing and structure of a snowbed plant communitya long-term experiment at Kilpisjärvi, Finnish Lapland. - Oikos 79: 155-166.

Walter, H. 1964. Die Vegetation der Erde. (Band 1). E. Ulmer, Stuttgart.

Walter, H. 1968. Die Vegetation der Erde. (Band 2). E. Ulmer, Stuttgart.

Welden, C. W., Slauson, W. L. and Ward, R. T. 1988. Competition and abiotic stress among trees and shrubs in northwest Colorado. - Ecology 69: 1566-1577.

Wilson, S. D. and Keddy, P. A. 1986a. Measuring diffuse competition along an environmental gradient: results from a shoreline plant community. - Am. Nat. 127: 862-869.

Wilson, S. D. and Keddy, P. A. 1986b. Species competitive ability and position along a natural stress/disturbance gradient. - Ecology 67: 1236-1242.

Wilson, S. D. and Shay, J. M. 1990. Competition, fire, and nutrients in a mixed-grass prairie. - Ecology 71: 1959-1967.

Wilson, S. D. and Tilman, D. 1991a. Components of plant competition along an experimental gradient of nitrogen availability. - Ecology 72: 1050-1065.

Wilson, S. D. and Tilman, D. 1991b. Interactive effects of fertilization and disturbance on an old-field plant community. - Oecologia 88: 61-71.

Wilson, S. D. and Tilman, D. 1993. Plant competition and resource availability in response to disturbance and fertilization. - Ecology 74: 599-611.

Zobel, M. 1992. Plant species coexistence-the role of historical, evolutionary and ecological factors. - Oikos 65: 314-320.

Zobel, M. 1997. The relative role of species pools in determining plant species richness-an alternative explanation for species coexistence? - Trends Ecol. Evol. 12: 266-269.

Subject Editor: Per Lundberg 